地すべり 第17巻 第 2 号

Journal of the Japan Society of Landslide 17-2 (1980)

\title{
シャフトグイの設計法
}

\section{Design of the Rigid Dowel Pile for Landslide Control}

\section{中 村 浩 之* \\ Hiroyuki NaKamura}

A cast-in-place pile of a diameter of $1.0 \mathrm{~m}$ to $3.5 \mathrm{~m}$ is used as a rigid dowel pile for landslide control, but the method of design of such a pile is not yet established.

The paper discusses the behavior of the rigid dowel pile used in the landslide area for increasing the shearing resistance at the sliding surface by the dowel force and also the method of design of such a pile.

The basic concept of design is that when a soil mass slides over a sliding surface, the pile tilts to produce subgrade reaction in the soil mass above and below the sliding surface and thus a dowel force at the sliding surface. And it is intended to resolve the equilibrium conditions of the forces loaded on the pile, to calculate the bending moment, shearing force, tilt and subgrade reaction acting on the pile and thus to obtain the basic conditions for design of the pile. This method of analysis is applicable to multi-layered soils. From the result of measurement of the earth pressure on a large diameter pile constructed actually in a landslide area, said method of design of the pile is adequate. It is also shown that a method of determining the pile casting position at which the pile will exhibits the dowel force fully from a diagram of distribution of the horizontal internal force obtainable by slope stability analysis.

\section{まえがき}

地すべりを抑止するためにクイ工を用いることが多く なり，その設計法の確立が望まれるようになってから久 しい。大口径ボーリングによる鋼管グイ插入工について はかなり理論的に解明されてきたが1),2),3)，これに比較 して大口径のクイ（シャフトグイ）に対しての解析が遅 れているように思われる。そこで本文ではシャフトグイ の設計とくに，クイにかかる曲げモーメント， セン断 力, 地艋反力やクイの変位等についての計算法を提案 し，諸賢の御批判をこらところである。したがってここ ではシャフトグィの断面計算については行なわれていな い。

シャフトグイは一般に地すべりの滑動推力が大きく, 鋼管グイでは計画安全率の確保が難かしい場合とか, 地 艋条件の関係で大口径ボーリングによる掘削が困難な場 合に用いられる。シャフトグイは一般に径が $1.5 \sim 3.5 \mathrm{~m}$ で，ライナープレートなどを利用し，たて孔を掘削し， これにコンクリートを充填して鉄筋コンクリートの柱体 を地すべり地内に建て込み, 地すべり土塊の推力に抵抗 させるものである。

シャフトグイの設計を行なうとき計画安全率を確保す るために必要な力を安定解析式より算定し, これを設計 外力として, ケーソン基礎の設計に準じて設計を行なう ことが多い。しかしシャフトグイの施工位置によっては
外力をうけたときのクイの挙動は異なる。同様なことは 一般に用いられている鋼グイによる地すべり抑止の場合 についてもいえることである。

一つはクイ背面の土圧を期待できない場合で, 図-1の A， Bのような場合である。 A の場合は道路の建設に伴 い地すべり地末端をカットする場合などがあり，このと きはシャフトは地すべり全推力に対抗できるように設計 される。また Bのような場合は地すべり地の上部に施工 された場合である。このとさは将来, クイより下方斜面 の土塊がすべり落ちてクイより上部斜面は安定を保つよ

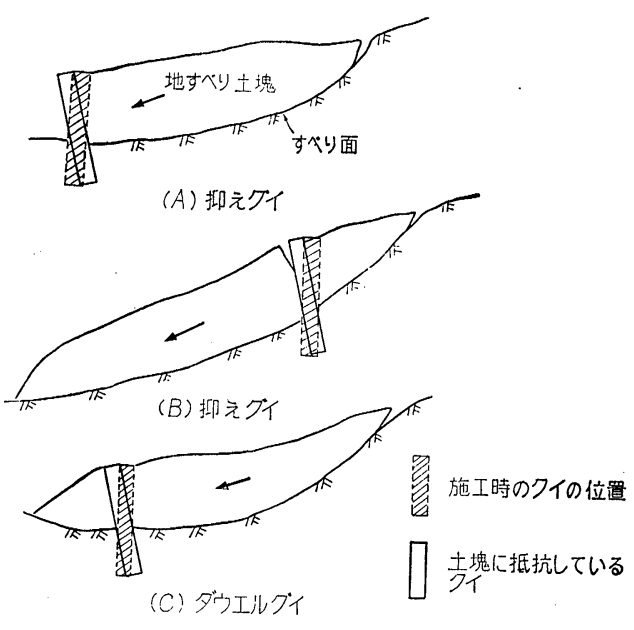

因-1 シャフトグイの機能 
らに施工される。A，Bいずれの場合も強度的（特に 曲げ破壊に対して）に普通の鋼管グイでは対抗できない 場合に, さらに剛度の大きいシャフトグイが用いられ る。

しかしCのように地すべり土塊中にシャフトグイが施 工される場合がある。このときのシャフトグイの設計は 前述のクイの設計とは異なる。そこで本文では主として このような場合のシャフトグイの設計について検討する ことにする。な执本文で用いられる記号は巻末の記号説 明で一括してまとめてある。

\section{1. クイにかかる設計外力の算定}

地すべりの安定解析によりクイによる必要抑止力を求 める必要がある。安定解析法にはいろいろな方法がある が，一般に斜面の安定解析ではスライス分割による限界 平衡法が用いられている。その中で特に地すべりの解析 では簡便法（Fellenius 法などいろいろな呼び名がある） が用いられ，この方法をさらに拡張して非円弧すべり面 にも適用している。簡便法の適用限界については他の文 献に譲るが，簡便法はすべり面の形状が極端に変化する 場合を除いて，かなりの精度の安全率を与えることがわ かった4)。

一方地すべり土塊内の内力分布を考光るとき，スライ ス間の壁に作用する内力をスライスの壁に垂直な力とセ ン断力に分解した場合，もっとも理論的とされる Morgenstern and Price 法によって, セン断力と垂直力の関 係を変化させ，いろいろ内力分布を検討した。これによ り, 安全率は内力分布にあまり左右されないのみならず,

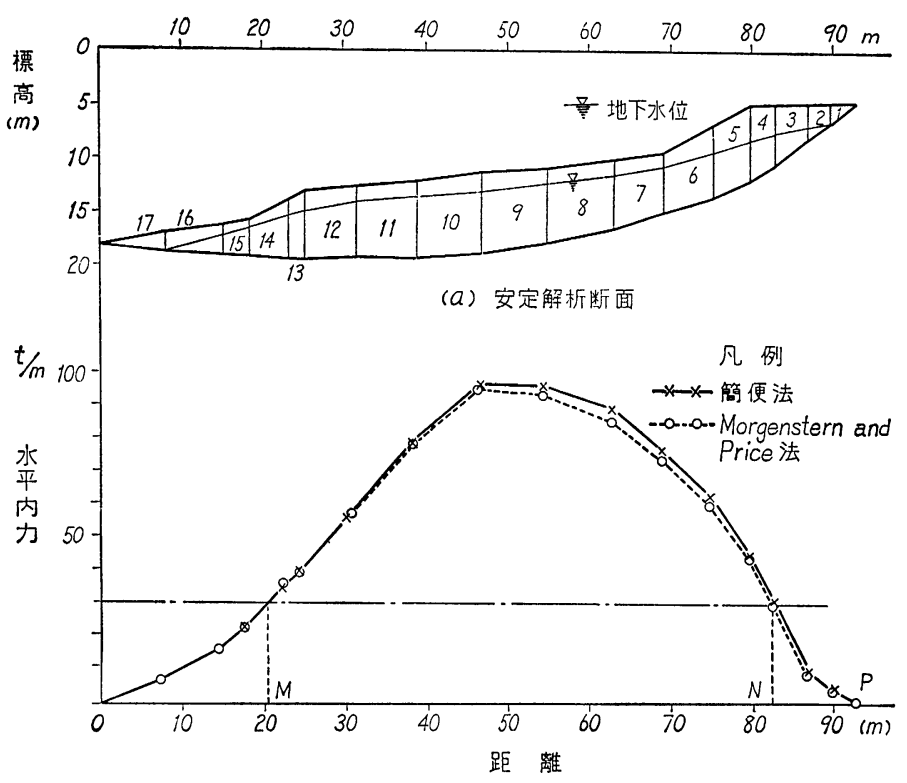

(b) 水平内力分布図

図-2 交定解析による水平内力分布の比皎
スライス壁に垂直な力の分布はほとんど変化がなく，ス ライス壁に作用するセン断力の分布のみ大きく変化する ことがわかった。クイの設計を行なら場合，セン断力は クイにかかる軸力として加算されるわけだが，これを無 視して行なえば，クイは安全側に設計できることになる。 したがってスライス壁に作用するセン断力を無視して， 水平力のみによってクイを設計しても問題がないことが わかる。さらに都合の良いことには，いろいろな安定解 析法によって求めた水平内力分布はほぼ同一の分布を示 すことがわかった。この一例を図-2に示す。この図は図 -2(a)に示す地すべり断面についてMorgenstern and Price 法と簡便法で解析し，地すべり土塊内の水平内力分布を 比較したものである。Morgenstern and Price 法では水 平内力分布は計算結果として得られる。一方簡便法では スライスの壁に作用する水平内力は，そのスライスの上 部斜面の推力とすべり面のセン断抵抗力の差の合計とし て求めることができるとした。すなわち計算式で示すと， 簡便式により(1)式が求められる。

$$
F=\frac{c \sum L+\sum(N-U) \tan \phi}{\sum T}
$$

また $i$ 番目のスライスに作用する限界平衡状態に打け る水平内力 $\left(P_{i}\right)$ は(2)式で示される。

$$
P_{i}=\left\{c \sum_{j=0}^{i} L_{j}+\sum_{j=0}^{i}\left(N_{j}-U_{j}\right) \tan \phi\right\} \cdot \frac{1}{F}-\sum_{j=0}^{i} T_{i} \cdots(2)
$$

したがって電子計算機を用いなければ計算できない式 を用いて水平内力分布を求めるより，手計算で簡単に求 まる簡便式を利用して解析を行なう方が一般には㬰用的 であるので，とくに厳密な解析を必要としない地すべり では簡便法で行ならことも可能である。ま たここではクイ工の基本的な概念を理解す るために，簡便式を利用して検討すること にする。

斜面の現状の安全率 $F$ を $\Delta F$ 高めるた めに必要な単位幅当りの水平抑止力を $P$ と すると, これは(3)式によって求めることが できる。

$$
\begin{aligned}
P= & \left\{c \sum L+\Sigma(N-U) \tan \phi\right\} \\
& -(F+\Delta F) \Sigma T \cdots \cdots \cdots . .
\end{aligned}
$$

またクイで抑止力を增加させるためには クイ 1 本当り

$$
H=\frac{P \times B}{n}
$$

ただし $B$ :地すべり幅, $n:$ クイの本数 の荷重を負担する必要がある。

ところで(3)式に拉けるPはクイの施工位 犆に関係なく計画安全率に対して求まる。 ここで問題になってくるのが地すべり土塊 内の水平内力分布である。例党ば図-2(a)の 
地すべりで限界平衡状態に扣ける内力分布を示すと図-2 (b)のようになり，もしこの地すべりが現状で安全率が 1.0 であり，これを安全率を 1.2 にまで上昇させるため には(3)式より $30 \mathrm{t} / \mathrm{m}$ の抑止力が必要であるとする。い ま必要水平抑止力線が水平内力分布曲線と交わる点が 図-2(b)上で 2 点求まるとする。その点の水平距離を地す ベり斜面の末端より与えて $M, N$ とする。もし $M, N$ 点に クイが施工されれば，クイは地すべ塊内に挿入され たクイとして挙動するが，もし OMあるいは NP の区間 にクイが施工されれば， $30 \mathrm{t} / \mathrm{m}$ の設計外力がかかったと きクイより下方斜面の土塊の反力を期待することがでさ なくなり，図-1のA，Bのようなクイとして設計しなけ ればならなくなる。そしてこれは区間 $\mathrm{MN}$ 内に施工され たクイと挙動は異なる。この場合, MN間にあるクイは クイより下方斜面の土塊の反力を期待することがでさる からである。したがってクイの設計はクイの下方斜面の 土塊の反力を期待でさるか否かで異なることになる。

ところでクイを弾性体と考える場合と, 剛体と考える 場合の判別方法は(5)，(6)式によって一般に行なわれてい る5)。

$$
\begin{aligned}
& \sqrt[4]{\frac{E_{s}}{4 E I}} \leqq \frac{2}{l} \\
& \sqrt[4]{\frac{E_{s}}{4 E I}}>\frac{2}{l}
\end{aligned}
$$

$$
\text { ここで } \begin{aligned}
E_{s}: & =2 K b \\
E I: & \text { クイの剛度 } \\
l & : \text { クイ長 }
\end{aligned}
$$

(5)式がなりたつときは剛体のクイと考えることができ， (6)式がなりたつときは弾性体のクイとして解析する必要 がある。一般に地すべり地で用いられる鋼管グイは弾性 体のクイとして，またシャフトグイは剖体グイとして解 析できる。(5)，(6)式より明らかなよらに，剛なクイか, 弾性体のクイかはクイの剛度, 径, 長さ打よび地盤条件 によって定まる值なので地すべりによってはたとえ直径 が $3.5 \mathrm{~m}$ あっても弾性体のクイとして解析する場合もあ るので, 設計にあたっては(5), (6)式で判別を行なら必要 がある。クイより下方斜面の土塊が期待でさないときに は，すべり面下部に抽いて判別式を適用するが，クイよ り下方斜面の土塊が期待できる場合は, すべり面の上下 で判別を行なら必要がある。しかしこの場合, すべり面 より上が剛体のクイで, すべり面より下部が弾性体のク イとして解析しなければならない場合もでてくる。この よらにすべり面の上下でクイの挙動が異なる場合は, 実 際には少ないと思われるので検討を行なわず, ここでは すべり面の上下でクイが剛体として挙動する場合につい てのみ考察することにする。

\section{2. クイの下方斜面の地盤反力が期待できない 場合の設計}

剛体として挙動するクイで, クイより下方斜面の反力 を期待できない場合, すなわち(3)式より求められた Pが クイの施工位直での水平内力 $P_{i}$ より大きい場合は, 図-3 に示すようにすべり面を仮想地表面とし，この面より突 出した部分に外力 $H か ゙$ 作用するとして解析を行なうこと ができる。すなわちこのよらな状態はケーソン基礎に水 平外力 $H か ゙$ 作用した場合と同様な解析法をとることが可 能で，この方法は現在シャフトグイの設計に用いられて いる。ここで問題になるのは設計外力の作用点の位直で あるが，すべり面より上のクイ長の $1 / 3$ だけの長さだけ すべり面から離れた位置に作用しても問題はなさそうで ある。したがってこの場合には図-3に示すようにすべ り面に仮想のクイ頭を持ち，ここにすべり面上部の柱体 の重量を垂直荷重 $(N)$ とし，すべり面上部の柱体の長 さの $1 / 3$ を腕の長さとし，これに設計荷重Hをかけたモ ーメント $(M)$ が作用するケーソンとして設計すればよ いことになる。

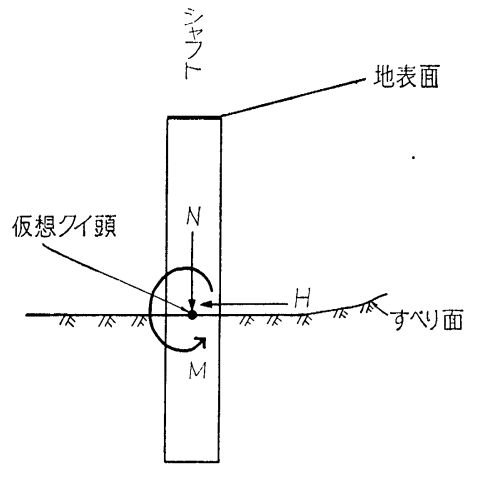

図-3 クイ下方斜面の地盤反力が期待できない場合の剛 なクイの解析法

\section{3. クイの下方斜面の地盤反力が期待できる場合}

クイより下方斜面の反力が期待できる場合，すなわち (3)式より求められた值がクイの施工位置での単位幅当り の水平内力 $P_{i}$ より小さい場合は, 地すべり土塊によるク イの拘束が十分期待できるので, 解析は前項の場合とは 異なってくる。これをモデル化して示すと図-4に示すよ うになる。図-4に従がって計算式を誘導する ${ }^{6)}$, 。すべ り面より上部のクイの長さを $l$, 下部を $l^{\prime}$ とし, 地すべ り土塊が $\Delta d$ だけ移動したとき,すべり面でセン断力 $H$ がクイに作用するものとする。ここでの解析は図-4に示 すようにすべり面より上部では 3 層の地盤より，またす ベり面下部では 2 層の地盤より構成されているものとし 図のような地盤反力係数を持つものとして行なわれる。 クイ底面での地盤反力 $(R)$ が台形分布をするときは, 
地すべり Vol. 17, No.2（1980）

水平力が釣合らとすると

$$
H-R-F_{m}=0 \text {. }
$$

$R$ は次式で求まる

$$
\begin{aligned}
& R=0 \ldots \ldots \ldots \ldots \ldots \\
& R^{\prime}=K_{s}^{\prime}\left(h^{\prime}-l^{\prime}\right) \theta A
\end{aligned}
$$

(8)式，(9)式はそれぞれすべり面の上下に対してのRで ある。

$F_{m}$ を水平方向の地盤反力度の和とするとすべり面の 上部では

$$
\begin{aligned}
F_{m} & =2 b\left[\int_{l_{1}+l_{2}}^{l_{1}+l_{2}+l_{3}} k_{3}\left(\frac{l-y}{l_{3}}\right)(h-y) \theta d y\right. \\
& +\frac{1}{2}\left\{k_{2}\left(h-l_{1}-l_{2}\right) \theta+k_{2}\left(h-l_{1}\right) \theta\right\} l_{2} \\
& \left.+\frac{1}{2}\left\{k_{1}\left(h-l_{1}\right) \theta+k_{1} h \theta\right\} l_{1}\right] \\
& =2 b\left\{\int_{l_{1}+l_{2}}^{l_{1}+l_{2}+l_{3}} k_{3}\left(\frac{l-y}{l_{3}}\right)(h-y) \theta d y\right. \\
& \left.+k_{2}\left(h-l_{1}-\frac{l_{2}}{2}\right) l_{2} \theta+k_{1}\left(h-\frac{l_{1}}{2}\right) \theta l_{1}\right\}
\end{aligned}
$$

すべり面下部では

$$
\begin{aligned}
F_{m}{ }^{\prime} & =2 b\left[\frac{1}{2}\left\{k_{1}{ }^{\prime} h^{\prime} \theta+k_{2}{ }^{\prime}\left(h^{\prime}-l_{1}\right) \theta\right\} l_{1}^{\prime}\right. \\
& \left.+\frac{1}{2}\left\{k_{2}{ }^{\prime}\left(h^{\prime}-l_{1}^{\prime}\right) \theta+k_{2}{ }^{\prime}\left(h^{\prime}-l_{1}{ }^{\prime}-l_{2}{ }^{\prime}\right) \theta\right\} l_{2}{ }^{\prime}\right] \\
& =2 b\left\{k_{1}{ }^{\prime}\left(h^{\prime}-\frac{l_{1}{ }^{\prime}}{2}\right) \theta l_{1}{ }^{\prime}+k_{2}{ }^{\prime}\left(h^{\prime}-l_{1}{ }^{\prime}-\frac{l_{2}{ }^{\prime}}{2}\right) \theta l_{2}{ }^{\prime}\right\}
\end{aligned}
$$

次にモーメントの釣合を考学る。いすすべり面上り上 と下のモーメントを $G, G^{\prime}$ とすると, すべり面でのモー メントの合計はすべり面の上下で $\Sigma M, \Sigma M^{\prime}$ であり次 式で示される。

$$
\begin{aligned}
& \Sigma M=R l+G-M_{B} \\
& \Sigma M^{\prime}=R^{\prime} l^{\prime}+G^{\prime}-M_{R^{\prime}}
\end{aligned}
$$

$$
\text { ここで }
$$

$$
G=2 b\left[\int_{l_{2}+l_{s}}^{l_{1}+l_{2}+l_{3}} k_{3} \frac{(l-y)}{l_{3}} y(h-y) \theta d y\right.
$$

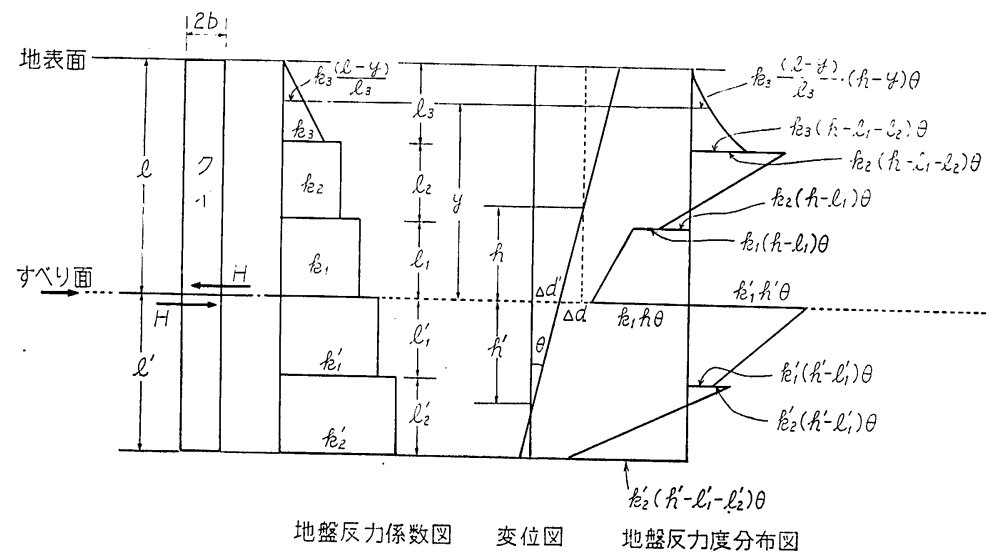

図-4 多層系地盤のシャフトクイ解析

$$
\begin{aligned}
& +k_{2}\left(h-l_{1}-\frac{l_{2}}{2}\right) l_{2} \theta \\
& \times\left\{l_{1}+\frac{k_{2}\left(3 h-3 l_{1}-2 l_{2}\right)}{2 k_{2}\left(h-l_{1}-\frac{l_{2}}{2}\right)} \cdot \frac{l_{2}}{3}\right\} \\
& \left.+k_{1}\left(h-\frac{l_{1}}{2}\right) \theta l_{1}\left\{\frac{k_{1}\left(3 h-2 l_{1}\right)}{2 k_{1}\left(h-\frac{l_{1}}{2}\right)} \cdot \frac{l_{1}}{3}\right\}\right\}
\end{aligned}
$$

また

$$
\begin{aligned}
G^{\prime} & =2 b\left[k_{1}{ }^{\prime}\left(h^{\prime}-\frac{l_{1}^{\prime}}{2}\right) \theta l_{1}^{\prime}\left\{\frac{k_{1}^{\prime}\left(3 h^{\prime}-2 l_{1}{ }^{\prime}\right)}{2 k_{1}^{\prime}\left(h^{\prime}-\frac{l_{1}^{\prime}}{2}\right)} \cdot \frac{l_{1}^{\prime}}{3}\right\}\right. \\
& +k_{2}{ }^{\prime}\left(h-l_{1}^{\prime}-\frac{l_{2}^{\prime}}{2}\right) \theta l_{2}^{\prime} \\
& \left.\times\left\{l_{1}^{\prime}+\frac{k_{2}^{\prime}\left(3 h^{\prime}-3 l_{1}^{\prime}-2 l_{2}^{\prime}\right)}{2 k_{2}^{\prime}\left(h^{\prime}-l_{1}^{\prime}-\frac{l_{2}^{\prime}}{2}\right)} \cdot \frac{l_{2}^{\prime}}{3}\right\}\right] \cdots \cdots(15)
\end{aligned}
$$

$M_{B}$ はクイの底面の地盤反力度に関するモーメントで あり, 鉛直方向の地艋反力度に対するモーメントは

$$
M_{B}{ }^{\prime}=\frac{4}{3} b^{4} K_{V} \cdot \alpha
$$

ただし $\alpha=0.589$

であり,クイ上面では

$$
M_{B}=0
$$

である。

$$
\text { ところで }
$$

$\Sigma M+\Sigma M^{\prime}=0$

なので

$$
G+G^{\prime}+R^{\prime} l^{\prime}-M_{B}{ }^{\prime}=0 .
$$

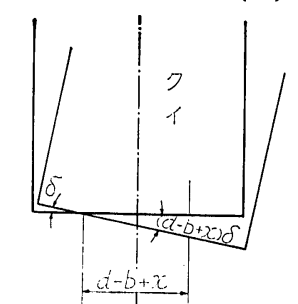


一方(7)式より

$$
\begin{aligned}
& H-F=H-R^{\prime}-F^{\prime}=0 \\
& \therefore F=R^{\prime}+F^{\prime} \quad \ldots \ldots \ldots . .
\end{aligned}
$$

(18)式，(20)式を $\theta ， h$ の連立方程式として解きそれぞれ を求めることができる。

次にクイ底面の地盤反力度が三角形になる場合のクイ にかかる地盤反力度は底面の一部が有効になるので，

$$
M_{B}{ }^{\prime}=K_{V} b^{4} \nu_{2}
$$

ここで

$$
\nu_{2}=\frac{2}{3} \sin ^{3} \beta \cos \beta+\frac{1}{4}(\pi-\beta)+\frac{1}{16} \sin 4 \beta
$$

(図-5参照)

クイ底面の面積が $A$ から $A^{\prime}$ に減少するとして， (18)，(20) 式を用いてまったく同様な計算によって $\theta, h$ を求める ことがでさる。

次に地すべり活動によりクイに水平方向の力がかかり, 地盤反力が作用し，それによってクイに発生する曲げモ ーメントとセン断力を求める計算を示す。眓-4よりすべ り面より上に深さ $y$ に拈ける曲げモーメントは

$0 \leqq y \leqq l_{1}$ では

$$
M_{y}=\sum M+H \cdot y-\left\{\frac{k_{1}}{6} \theta y^{2}(3 h-y)\right\} 2 b
$$

$$
\begin{aligned}
& l_{1} \leqq y \leqq l_{1}+l_{2} \\
& M_{y}=\sum M+H \cdot y-\left\{\frac{k_{1}}{6} \theta l_{1}^{2}\left(3 h-l_{1}\right)\right. \\
& +\frac{k_{1} \theta l_{1}\left(2 h-l_{1}\right)}{2}\left(y-l_{1}\right) \\
& \left.+\frac{k_{2}}{6} \theta\left(y-l_{1}\right)^{2}\left(3 h-2 l_{1}-y\right)\right\} 2 b
\end{aligned}
$$

また $l_{1}+l_{2} \leqq y \leqq l$ では

$$
\begin{aligned}
M_{y}= & \sum M+H \cdot y-\left\{\frac{k_{1}}{6} \theta l_{1}^{2}\left(3 h-2 l_{1}\right)\right. \\
& +\frac{k_{2} \theta}{6} l_{2}^{2}\left(3 h-3 l_{1}-l_{2}\right) \\
& +\frac{k_{1} \theta l_{1}}{2}\left(2 h-l_{1}\right)(y-h) \\
& +\frac{k_{2} \theta}{2} l_{2}\left(2 h-2 l_{1}-l_{2}\right)\left(y-l_{1}-l_{2}\right) \\
& \left.+\int_{l_{1}+l_{2}}^{y} \frac{k_{3} \theta}{l_{3}}(l-x)(h-x)(y-x) d x\right\} 2 b
\end{aligned}
$$

またすべり面より下の $y^{\prime}$ に拈ける曲げモーメントは $0 \leqq y^{\prime} \leqq l_{1}^{\prime}$ では

$$
M_{y}^{\prime}=\sum M^{\prime}+H y^{\prime}-\left\{\frac{k_{1}^{\prime}}{6} \theta y^{\prime 2}\left(3 h-y^{\prime}\right)\right\} 2 t
$$

$l_{1}^{\prime} \leqq y^{\prime} \leqq l_{1}^{\prime}+l_{2}^{\prime} \quad$ では

$$
M_{y}{ }^{\prime}=\sum M^{\prime}+H y^{\prime}-\left\{\frac{k_{1}{ }^{\prime}}{6} \theta l_{1}{ }^{2}\left(3 h^{\prime}-l_{1}{ }^{\prime}\right)\right.
$$

$$
\begin{aligned}
& +\frac{k_{1}^{\prime} \theta l_{1}^{\prime}}{2}\left(2 h^{\prime}-l_{1}^{\prime}\right)\left(y^{\prime}-l_{1}^{\prime}\right) \\
& \left.+\frac{k_{2}^{\prime}}{6} \theta\left(y^{\prime}-l_{1}^{\prime}\right)^{2}\left(3 h^{\prime}-2 l_{1}^{\prime}-y^{\prime}\right)\right\} 2 b
\end{aligned}
$$

一方すべり面より上で深さ $y$ に怙けるセン断力は $0 \leqq y \leqq l_{1}$ に拉いて

$$
S_{y}=H-\left\{\frac{k_{1} \theta}{2} y(2 h-y)\right\} 2 b \text {. }
$$

$l_{1} \leqq y \leqq l_{1}+l_{2}$ において

$$
S_{y}=H-\left\{\frac{k_{1} \theta l_{1}}{2}\left(2 h-l_{1}\right)+\frac{k_{2} \theta}{2}\left(y-l_{1}\right)\left(2 h-l_{1}-y\right)\right\} 2 b
$$

また $l_{1}+l_{2} \leqq y \leqq l$ において

$$
\begin{aligned}
S_{y} & =H-\left\{\frac{k_{1} \theta l_{1}}{2}\left(2 h-l_{1}\right)+\frac{k_{2} \theta l_{2}}{2}\left(2 h-2 l_{1}-l_{2}\right)\right. \\
& \left.+\int_{l_{1+l_{2}}}^{y} \frac{k_{3} \theta}{l_{3}}(l-x)(h-x) d x\right\} 2 b \cdots \cdots \cdots \cdots \cdots \cdots
\end{aligned}
$$

一方すべり面より下 $y^{\prime}$ に括けるセン断力は $0 \leqq y^{\prime} \leqq l_{1}^{\prime}$ では

$$
S_{y}{ }^{\prime}=H-\left\{\frac{k_{1}{ }^{\prime} \theta}{2} y^{\prime}\left(2 h^{\prime}-y^{\prime}\right)\right\} 2 b
$$

$l_{1}^{\prime} \leqq y^{\prime} \leqq l_{1}^{\prime}+l_{2}^{\prime}$ において

$$
\begin{aligned}
S_{y}^{\prime}= & H-\left\{\frac{k_{1}^{\prime} \theta l_{1}^{\prime}}{2}\left(2 h^{\prime}-l_{1}^{\prime}\right)\right. \\
& \left.+\frac{k_{2}^{\prime} \theta}{2}\left(y^{\prime}-l_{1}^{\prime}\right)\left(2 h^{\prime}-l_{1}^{\prime}-y^{\prime}\right)\right\} 2 b
\end{aligned}
$$

以上すべり面を挾んでの 5 層系地盤に怙けるクイに作 用する地盤反力度, 変位, 曲げモーメント, セン断力につ いての計算を行ならことが可能となったが，さらに複雑 な地盤構成に対しても同様なやり方で計算が可能である。

\section{2 層系地盤におけるシャフトグイの設計}

建設省土木研究所の試験地である猿供養寺地すべり地 内にシャフトグイが打設され，このクイにかかる土圧が 測定された。クイの直径は $1.5 \mathrm{~m}$ ですべり面より下に $6 \mathrm{~m}$, すべり面より地表面まで $4 \mathrm{~m}$ の長さをもっている。 猿供養寺地すべりの地艋構成は図-6に示す。いまヶー ソンの設計法に準拠してすべり面上下に批ける水平方向 の地盤反力係数を求める。

すべり面上部で

$$
\begin{aligned}
E_{0}= & 28 N=28 \times 4 q_{u}=28 \times 4 \times 0.65=72.8\left(\mathrm{~kg} / \mathrm{cm}^{2}\right) \\
& \left(\because q_{u}=0.65 \mathrm{~kg} / \mathrm{cm}^{2}, \text { 標準貫入值 } N=4 q_{u}\right) \\
k_{0}= & 0.040 \times \alpha^{\prime} \times E_{0} \\
= & 0.040 \times 1.0 \times 72.8=2.685\left(\mathrm{~kg} / \mathrm{cm}^{2}\right) \\
& \left(\because \alpha^{\prime}=1.0 \text { 常時 }\right) \\
A_{H}= & 2 b \times l=150 \mathrm{~cm} \times 300 \mathrm{~cm}=45,000 \mathrm{~cm}^{2} \\
B_{H}= & \sqrt{A_{H}}=212.13 \mathrm{~cm}
\end{aligned}
$$




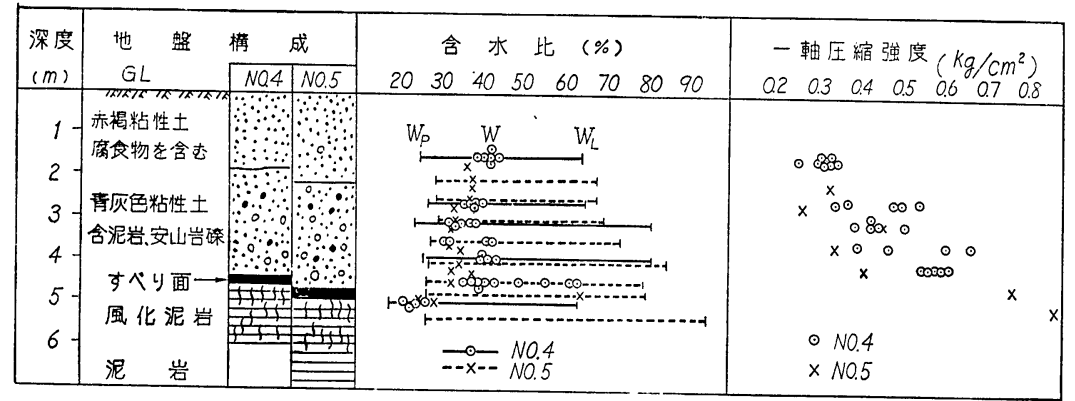

図-6 猿供養寺地すべり地盤構成図

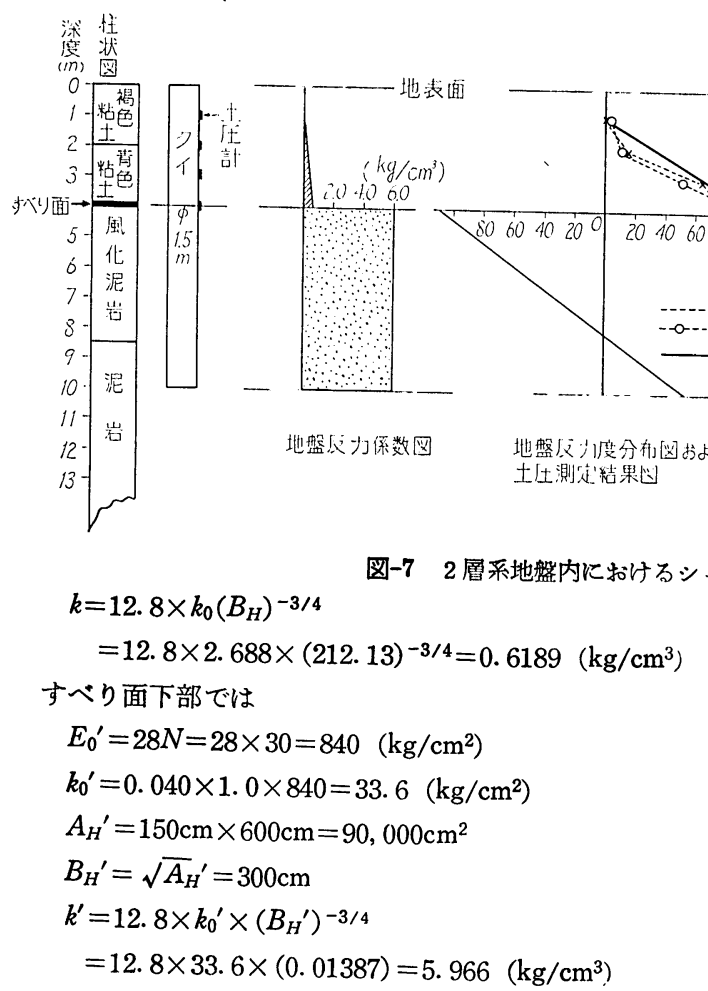

次にクイ底面に护ける鉛直および水平地盤反力度の推 定を行なう。鉛直方向の地盤反力係数 $K_{V}$ は

$$
\begin{aligned}
K_{V_{0}}= & 0.033 \alpha^{\prime} E_{0}^{\prime} \quad\left(\alpha^{\prime}=1.0 \text { 常時 }\right) \\
= & 0.033 \times 1.0 \times 840=27.72\left(\mathrm{~kg} / \mathrm{cm}^{2}\right) \\
K_{V}= & 12.8 \times K_{V_{0}}\left(B_{V}\right)^{-3 / 4} \\
= & 12.8 \times 27.7 \times(150)^{-3 / 4} \\
& \left(\because B_{V}=2 b=\text { クイの直径 }\right) \\
= & 8,2779\left(\mathrm{~kg} / \mathrm{cm}^{3}\right)=8277.9\left(\mathrm{t} / \mathrm{m}^{3}\right) \\
K_{S}= & \lambda \times K_{V}=\frac{1}{3} \times 8.2779=2.7593\left(\mathrm{~kg} / \mathrm{cm}^{3}\right)
\end{aligned}
$$

さて図-7に示すよらなすべり面上下の地盤がそれぞれ 1 層より構成されている地盤内でのシャフトグイの計算 を示す。多層系地盤と同様に考えると水平方向の釣合よ $\eta$

$$
H-R-F=0
$$

すべり面上部で $R$ ，すべり面下部では $K^{\prime}$ とするとク

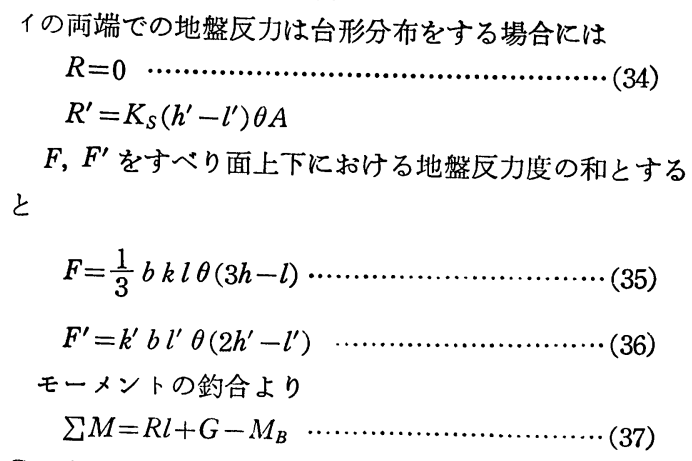$$
R=0
$$$$
R^{\prime}=K_{S}\left(h^{\prime}-l^{\prime}\right) \theta A
$$

$F, F^{\prime}$ をすべり面上下に拈ける地盤反力度の和とする と

$$
\begin{gathered}
F=\frac{1}{3} b k l \theta(3 h-l) \cdot \\
F^{\prime}=k^{\prime} b l^{\prime} \theta\left(2 h^{\prime}-l^{\prime}\right) \\
\text { モーメントの釣合より } \\
\sum M=R l+G-M_{B}
\end{gathered}
$$$$
\text { モーメントの釣合より }
$$

$G$ は水平方向の地盤反力度のすべり面の上下に打けるモ メントであるから

$$
\begin{aligned}
G & =\frac{b}{6} k \theta l^{2}(2 h-l) \\
G^{\prime} & =\frac{b}{3} k^{\prime} \theta l^{\prime 2}\left(3 h^{\prime}-2 l^{\prime}\right)
\end{aligned}
$$

クイの両端面における地盤反力度に関するモーメント は

$$
\begin{aligned}
& M_{B}=0 \cdots \ldots \ldots \ldots . . . . . \\
& M_{B}{ }^{\prime}=\frac{4}{3} b^{4} K_{V} \alpha \theta .
\end{aligned}
$$

また $\sum M+\Sigma M^{\prime}=0$ より

$$
\frac{b}{6} k l^{2}(2 h-l)+\frac{b}{3} k^{\prime} l^{\prime 2}\left(3 h^{\prime}-2 l^{\prime}\right)
$$




\section{シャフトグイの設計法}

$$
+K_{S}\left(h^{\prime}-l^{\prime}\right) l^{\prime} A-\frac{4}{3} b^{4} K_{V} \alpha=0 .
$$

また $H-R-F=H-R^{\prime}-F^{\prime}=0$ より

$$
\frac{b}{3} k l(3 h-l)=K_{S}\left(h^{\prime}-l^{\prime}\right) A+b l^{\prime} k^{\prime}(2 h-l)
$$

また $H-F=0(\because R=0)$ より

$$
H-\frac{b}{3} k l \theta(3 h-l)=0 \text {. }
$$

あるいは $H-R^{\prime}-F^{\prime}=0$ より

$$
H-K_{S}\left(h^{\prime}-l^{\prime}\right) \theta A-k^{\prime} b l^{\prime} \theta\left(2 h^{\prime}-l^{\prime}\right)=0 \cdots
$$

さらにすべり面から上下に $y, y^{\prime}$ だけ離れた地点に拉 ける曲げモーメントは

$0 \leqq y \leqq l$ に捇いて

$$
\begin{aligned}
M_{y} & =\frac{b}{6} k \theta l^{2}(2 h-l)-H y \\
& +\frac{b k \theta}{6 l} y^{2}\left(6 h l-2 l y-2 h y+y^{2}\right)
\end{aligned}
$$

また $0 \leqq y^{\prime} \leqq l^{\prime}$ に捻いて

$$
M_{y}^{\prime}=\frac{b}{6} k \theta l^{2}(2 h-l)+H y^{\prime}-\frac{b}{3} k^{\prime} \theta y^{\prime 2}\left(3 h^{\prime}-y^{\prime}\right)
$$

一方すべり面かう上下に $y, y^{\prime}$ 離れた地点でのセン断 力は

$$
\begin{aligned}
0 \leqq y & \leqq l \text { では } \\
S_{y} & =H-\frac{b}{3} k \theta y(3 h-y) \cdots \\
0 \leqq y^{\prime} & \leqq l^{\prime} \text { では } \\
S_{y}{ }^{\prime} & =H-b k^{\prime} y^{\prime} \theta\left(2 h^{\prime}-y^{\prime}\right)
\end{aligned}
$$

ここで $H=220 \mathrm{t}$ とすれば(42)式より

$\frac{1}{6} \times 618.9 \times 0.75 \times(3.0)^{2}(2 h-3.0)$

$+\frac{1}{3} \times 5966 \times 0.75 \times(6.0)^{2}\left(3 h^{\prime}-12\right)$

$+2759.2\left(h^{\prime}-6.0\right) \times 6.0 \times 3.14(0.75)^{2}$

$-\frac{4}{3}(0.75)^{4} \times 8277.9 \times 0.589=0$

$\therefore h=-136.67 h^{\prime}+591.67$

また(43)式より

$$
\begin{aligned}
& \frac{1}{3} \times 0.75 \times 618.9 \times 3(3 h-3) \\
& \quad=2759\left(h^{\prime}-6.0\right) \times 3.14 \times(0.75)^{2} \\
& \quad+0.75 \times 6 \times 5966\left(2 h^{\prime}-6\right) \\
& \quad \therefore h=-135.68+42.059 h^{\prime} \ldots \ldots . . .
\end{aligned}
$$

したがって(50), (51)式より

$$
h=35.48 \mathrm{~m}, h^{\prime}=4.07 \mathrm{~m}
$$

したがって(44)式より

$$
220-\frac{1}{3} \times 618.9 \times 0.75 \times 3 \times \theta(3 \times 35.48-3)=0
$$$$
\therefore \theta=4.5819 \times 10^{-3} \text { (ラジアン) }
$$

ところで底面の地盤反力分布が台形か，三角形分布か を調べる必要がある。

$$
q_{1,2}=\frac{w l-U}{A} \pm K_{V} b \theta
$$

$$
こ こ て ゙
$$

$$
\begin{aligned}
& U=1.0 \times 3.14 \times\left(\frac{1.5}{2}\right)^{2} \times(3+6)=15.89 \mathrm{t} \\
& w=2.5 \times\left(\frac{1.5}{2}\right)^{2} \times 3.14=4.42 \mathrm{t} / \mathrm{m} \\
& l=10 \mathrm{~m} \\
& A=1.766 \mathrm{~m}^{2} \\
& K_{V}=8277.9\left(\mathrm{t} / \mathrm{m}^{3}\right) \\
& \theta=4.5819 \times 10^{-3}
\end{aligned}
$$

であるから

$$
\begin{aligned}
q_{1.2} & =\frac{44.15-15.89}{1.766} \pm 8277.9 \times 0.75 \times 4.5819 \times 10^{-3} \\
& =44.4\left(\mathrm{t} / \mathrm{m}^{2}\right) \text { あるいは }-12.44 \mathrm{t} / \mathrm{m}^{2}
\end{aligned}
$$

したがって底面の地艋反力は三角形分布であることが わかる。

$$
q_{1}=K_{V} \theta d
$$

より $d=1.1706 \mathrm{~m}$

また $d=b(1+\cos \beta)$ より $\cos \beta=0.56083$

$\therefore \beta=0.9754$ (ラジアン)

したがって

$$
A^{\prime}=b^{2}(\pi-\beta+\sin \beta \cdot \cos \beta)
$$

より減少した底面 $A^{\prime}$ は $A^{\prime}=1.4795 \mathrm{~m}^{2}$ となる。したが ってこの $A^{\prime}$ を用いて(42), (43)式よりくり返し計算で改め て $h, h^{\prime}$ が求まり

$$
\begin{aligned}
& h=34.763 \mathrm{~m} \\
& h^{\prime}=4.025 \mathrm{~m}
\end{aligned}
$$

となる。そして(44)式より $\theta=4.679 \times 10^{-3}$ (ラジアン) が 求まり，すべり面の上下に执忷るモーメント，七ン断力 は(46)，(47)，(48)，(49)式によって求まる。

$$
\begin{aligned}
M_{y}= & \frac{0.75}{6} \times 618.9 \times\left(4.679 \times 10^{-3}\right)(3.0)^{2} \\
& \times(2 \times 34.763-3.0)-220 y \\
& +\frac{0.75}{6 \times 3} \times 618.9 \times\left(4.679 \times 10^{-3}\right) y^{2}(6 \times 34.763 \times 3 \\
& \left.-2 \times 3 \times y-2 \times 34.763 \times y+y^{2}\right) \\
\therefore \quad & M_{y}=216.73-220 y+75.463 y^{2} \\
& \quad-9.108 y^{3}+0.1206 y^{4} \ldots \ldots \ldots \ldots \ldots \ldots \ldots \ldots(54)
\end{aligned}
$$

また

$$
\begin{aligned}
M_{y}{ }^{\prime}= & \frac{0.75}{6} \times 618.9 \times\left(4.679 \times 10^{-3}\right)(3.0)^{2} \\
& \times(2 \times 34.763-3.0)+220 y \\
- & \frac{0.75}{3} \times 5966 \times\left(4.679 \times 10^{-3}\right) \\
& \times y^{\prime 2}\left(3 \times 4.0256-y^{\prime}\right)
\end{aligned}
$$


$\therefore M_{y}^{\prime}=216.73+220 y^{\prime}+6.9787 y^{\prime 3}-84.280 y^{\prime 2}$

また

$$
\begin{aligned}
& S_{y}=220-\frac{1}{3} \times 0.75 \times 618.9\left(4.679 \times 10^{-3}\right) y \\
& \times(3 \times 34.763-y) \\
& \therefore S_{y}=220+0.7239 y^{2}-75.50 y \\
& S_{y}{ }^{\prime}=220-5966 \times 0.75\left(4.679 \times 10^{-3}\right) y^{\prime} \\
& \times\left(2 \times 4.0256-y^{\prime}\right) \\
& \therefore S_{y^{\prime}}{ }^{\prime}=220+20.936 y^{\prime 2}-168.56 y^{\prime}
\end{aligned}
$$

さらにすべり面上部に批ける深度 $y$ に和ける地盤反力 は

$$
\begin{aligned}
& k \frac{(l-y)}{l}(h-y) \theta=618.9 \times \frac{(3-y)}{3}(35.480-y) \\
& \times 4.679 \times 10^{-3}
\end{aligned}
$$

よりまたすべり面下部では

$$
k^{\prime} \theta\left(y^{\prime}-h^{\prime}\right)=5966 \times 4.679 \times 10^{-3}\left(y^{\prime}-4.0256\right) \text {. }
$$

\section{より求まる。}

以上により曲げモーメント図，セン断力図，地盤反力 度分布図を示すと図-7になる。ここで地盤反力度分布図 上に現場における土圧測定結果を同時に示した。土圧測 定はすべり面上部の山側の面に打いてのみ測定されたが, すべり面近くで約 $90 \mathrm{t} / \mathrm{m}^{2}$ の最大土印が測定された。す なわち最大土圷の発生とともに周辺土塊で破壊したもの と推定される。破壞時に拁ける土压はすでに報告したよ らに次式で求まる8)。

$$
\begin{aligned}
P(y) & =\left\{N_{\phi} \gamma_{t}(l-y)+2 \sqrt{N_{\phi}} C\right\} \\
& \times\left\{2 b+2(l-y) \cot \delta \cdot \sin \alpha \cdot \frac{\pi \alpha}{180}\right\}
\end{aligned}
$$

ここですべり面に拈ける破壊時に拈ける土圧を求めると

$l=4.0 \mathrm{~m}, \quad r_{t}=2.0 \mathrm{t} / \mathrm{m}^{3}, \quad y=0, c=\frac{q_{u}}{2}=0.3 \mathrm{~kg} / \mathrm{cm}^{2}$, $\phi=0$ とすると

$$
\alpha=45^{\circ}+\frac{\phi}{2}, \quad \delta=45^{\circ}-\frac{\phi}{2}, \quad N_{\phi}=\frac{(1+\sin \phi)}{(1-\sin \phi)}
$$

より

$$
\begin{aligned}
P(0) & =\{1 \times 2.0 \times(4-0)+2 \sqrt{ } \mathrm{T} \times 3.0\} \\
\times & \left\{0.75 \times 2+2(4-0) \times 1.0 \times 0.707 \times \frac{45 \times 3.14}{180}\right\} \\
& =83.02 \mathrm{t} / \mathrm{m}^{2}
\end{aligned}
$$

となる。したがって移動土塊のすべり面周辺の土塊が破 壊され，それ以後は地すべり土塊の移動とともに，クイ は徐々に傾むいていったものと考党られる。

現場に括けるシャフトグイにかかる土圧測定例が少な いので明言はできない地すべり地中に建て込まれたシャ フトグイの設計は今ままで述べてきたよらなやり方で行 ならことができると考觉られる。

\section{おわりに}

クイエで地すべり土塊を抑止する場合に問題となる点 は,クイが待ち受け工法の一種であるといらことである。 すなわちクイは地すべり土塊がすべり，ある程度の変位 を生じないと所定の力を発揮しないといら点である。し たがって地すべりの許容変位量をどの程度に規定するか はクイ工設計の重要な因子になるが，この点の配虑はい ままであまりなされていない。当然シャフト工の設計の 場合もクイの变位量を決定してやらなければならないが, 地すべりの重要性等によって左右され一概には決められ ないのは勿論である。しかしこのためには地すべり斜面 の変形解析と現在実施されている限界平衡解析の関係に ついても明らかにする必要があり，今後の大きな検討課 題となることは明らかである。また最近では鋼管グイで る管内に特殊鉄筋やヶーブルを拽入するなど断面の補強 が可能になり，大きな外力に耐兄られるようになった が, 変位量の点もクイ本数を增すことによってシャフト グイよりも小さな変位量で大きな外力に対抗できること も考党られ，この点についての検討もクイ工設計では考 える必要がある。

さらに本文ではほとんど検討しなかったが，すべり面 の上下でクイの挙動の異なるクイの設計法などまだまだ クイエに関しては問題が山積しているので，今後さらに 研究を進めてゆくつもりである。

最後に本文をまとめるにあたって御指導いただいた藤 田地すべり研究室長に心から謝意を表す。

\section{〈記号説明〉}

$A, A^{\prime} ;$ クイの底面積
$B$; 地すべり幅
$b ;$;イの半径
$c ;$ 七の粘着力
$E$; 弾性係数

$E_{0} ;$ 地盤变化を考慮した換算变形俰数 $\left(\mathrm{kg} / \mathrm{cm}^{2}\right)$

$F$; 安全率

$F_{m} ;$ 水平方向の地盤反方度の和

$G$; すべり面上下のモーメント

$H$; クイにかかる設計外力

$I$; 断面二次モーメント

$h$; すべり面からクイの回転の中心までの距離

$K$; 地盤の横方向反力係数

$K_{S}$; 水平方问のセン断バネ係数 $\left(\mathrm{kg} / \mathrm{cm}^{2}\right)$

$K_{V}$; 鉛直方向の地盤反力係数

$k, k^{\prime}$; 水平方向の地盤反力係数 $\left(\mathrm{kg} / \mathrm{cm}^{3}\right)$

$L ;$ すべり面長

$l, l^{\prime} ;$ クイ長

$M$; モーメント 


\author{
$M_{B}, M_{B}{ }^{\prime}$; クイ底面の地艋反力度に関するモー \\ メント \\ $N$; 垂直力 \\ $n$; クイの本数 \\ $P$; スライス壁に作用する水平内力 \\ $q_{u} ;$ 一軸圧縮強度 \\ $T$; 地すべり推力 \\ $U$; 間隙水圧 \\ $y, y^{\prime} ;$ すべり面からの距離 \\ $\theta$; クイの回転角 \\ $\lambda$; 鉛直地盤反力係数に対する \\ 水平方向セン断ばね係数比 \\ $w$; クイの単位体積重量
}

\section{参考文献}

1）福岡正巳 (1972)：地すべりと土質力学，「地すべりと対策
に関する研究討論会概要」,地すべり学会, 全国地すべが け崩れ対策協議会, pp. 51〜 55.

2）福本安正（1972）：地すべり防止グイの挙動に関係する研 究，「土質工学会論文報告集」Vol. 12, No. 2, pp61 73.

3）中村浩之 (1977)：地スベリ防止対策グイの三つの機能, 「土質工学会論文報告集」Vol. 17, No. 1, pp. 99 109.

4）中村浩之 (1978)：地すべり斜面の安定計算式の検討，「士 木技術資料」Vol. 20，No. 8，pp21 26.

5） 日本道路協会（1970）：道路橋下部構造物設計指針 ケーソ ン基礎の設計編, pp. $2 \sim 3$.

6）日本道路協会 (1970)：道路橋下部構造物設計指針ケーソン 基礎の設計編, pp. $29 \sim 78$.

7）浅間達雄, 他 (1973)：〈い未よびヶーソン基礎の設計計算 例, 山海堂, pp. 136 200.

8）中村浩之（1970）：地すべり防止対策グイにかかる土圧とそ の設計,「地すべり」, Vol. 7, No. 2, pp. 8〜12.

（原稿受理日 昭和55年 4 月 25 日）
評 $\rangle$

\section{$「 土$ 木地質学」}

道路・鉄道建設, 宅地造成, 高層ビルの建築など, 最 近は各種の土木・建設工事が益々大規模に行なわれてい る。また各種の地盤災害発生に際して，その地盤条件な らびに建造物などの安全性に関する問題が取りざたされ ている。これら問題の解決について, その多くは土木地 質学の認識や学識に負うところが大きく，その必要性が 極度に高まりつつある。しかしこの部面の書籍や印刷物 はまとまうたものが少なく，より適切な出版物が望まれ ていた。このたび応用地質学・地盤災害科学関係の権威

松野久也・山口真一両博士の監訳により, 標題のQ. ザルバ・V.メンツルの原著書が翻訳出版されたことは 誠に有意義なことである。

本書の内容は上巻（序章, 第 1 章〜第10章）：地質学 者と土木技師との協力，地質調査，地質図および断面図， 岩石の力学的性質, 地下探査, 地球物理的方法, 岩石の 風化, 斜面移動および地すべり, 掘削および岩盤のワー カビリティ, 建材鉱床の地質調査, 建築物および産業構 造物の基礎，下巻（第11章～第14章）：道路および鉄道, トンネルおよび地下発電所, 水力構造物のための土木地 質調査, 地域計画および環境政策における地質調查の課 題, となっている。

従来土木地質学に関する記述は, 地質学あるいは応用 地質学の専門書に数ページ述べられているのみで, 常に 物足りない思いをしたが，一読して大きな満足感を与え てくれる。本書はいくつかの独立したテーマのもとに記 述されているが, 各種の地質・地盤条件と土木・産業構 造物との関係を，実に豊富な実例と図版・写真を使用し て解説している。訳語も統一されているので文章は理解 し易い。また素晴らしい図版の助けもあって, 楽しみつ つ新しい土木地質学の要点を概観することが出来, 理論 と実際の問題を身近なものとして理解し易くしている。 第 1 章〜第 6 章までは, 土木地質学ともっとも関係の深

\section{Q. ザルバ・V.メンツル共著}

松野久也・山口慎一監訳

大明堂, 1980 , 上・下 528 頁

い地質学・岩石学・地球物理学の調査手法を中心とした 基本的な問題をとりあげている。特に地下探査等の問題 と関係の染い地質・サウンデイング・ボーリングコアの 判読, 岩石の力学的性質と風化特性などについて, 現実 に必要なポイントをとり出し, 理論と実際面の理解と対 㐫を容易にしている。第 6 章までを基礎篇とすれば第 7 章以降はいわば応用篇であり本論でもある。また必要に 応じ, どの章から諳みはじめても理解し易いように述べ てあり気楽に頁をくくることが出来る。

第 7 章は早速地すべりのテーマがとり挙げられており, その原因・分類・斜面安定など手際よくとりまとめられ ている。第 $8 \cdot 9 \cdot 10$ 章は, いずれも岩盤の削剝や建築 材・鉱床・各種岩盤の土木地質学的評価について系統的 にのベられている。下巻でとり挙げている各テーマは, 構造的サイトの問題だけでなく，更に線的・面的に把握 すべき土木地質学的課題について子れている。道路・鉄 道・ダムサイト・地域計画などの推進にあたっては，技 術の基本的な問題とともに社会・経済など多面的に考察 さるべき点が多い。第14章の中で「地質条件および環境 に対する人間活動の正しい影響の理解があって初めて計 画が可能となる」と訳出されているが，吾々の生活の舞 台が質量とも、変革を来しつつある昨今，自然に対し土 木地質学的技術をどのように対応させてゆくのか重要な 課題である。このような要請を満すためにも，関係者に とって本書は見逃すことの出来ない専門書であることは 勿論, 専門外の人にとっても恰好の教養書として広く一 読されるべき貴重なほん訳書である。一方原著者らはか つて地すべりに関する名著書を世に出している。このよ うな原著者が書かれた, 地すべりを含む土木地質学の名 書を, 本書によって日本語で早速読むことが出来るのは 誠に幸いである。 (中村三郎) 


\section{シャフトグイの設計法}

「地すべり」Vol. 17, No.2（通巻第62号）1980年（昭和55年）9月

中村 浩之

地すべりを防止するために直径 $1.0 \sim 3.5 \mathrm{~m}$ の現場打ちグイが岡なクイとして用いられることがあるが，こ のクイの設計方法はまだ確立されていない。本文は主としてダウェル力によってすべり面でのセン断抵抵力を 增加するために用いられるシャフトグイの地すべり地内での挙動や設計方法について述べたものである。

設計の基本的な考方方は地すべり土塊がすべり面上を滑動するとき，クイが回転し，すすべり面の上下の土塊 内で地船反力が発生し，すべり面にダウェル力が生じるものとしている。そしてこのときクイに作用する力の 釣合条件を解さ，クイに発生するモーメント，七ン断力，変位，地盤反力分布を求め，クイを設計するための 基本条件を求めるものである。解析は多層系地盤について行なわれる。

な扣本文ではダウエル力を発揮するクイの施工位置を斜面安定解析より求めた水平内力分布図より決定する 方法を述べるとともに実際に地すべり地内に打設されたシャフトグイに作用する土圧測定結果より，クイの設 計方法が適当であることを示す。

再滑動型地すべり面の $c, \phi$ とその変化

「地すべり」Vol. 17，No.2（通巻第62号）1980年（昭和55年）9月

玉文文吾

再滑動型地すべり一連続した地すべり面が地層中に既存し，降雨などの誘因によって滑動一にお゙いて，地す ベり粘土のせん断強度定数は, ダイレタンシーに関係するところの厚さ，有効土かぶり応力によって決定され るが，これが滑動を開始するとき，厚さが $3 \mathrm{~mm}$ 以下の場合， $c^{\prime} \fallingdotseq 0, \phi^{\prime}>0$ の状態で均衡がくずれるため, 間隙水圧の作用が大きく影響する。

移動量の增加とともに $c^{\prime}>0$ になり, 条件によっては $\phi^{\prime}$ も多少増加, 加えて負の過剩間隙水圧む発生する ので, 安全率にも変化が現われるようになる。

地すべり地における地下水変動現象の解析

「地すべり」Vol. 17，No.2（通巻第62号）1980年（昭和55年）9月

吉松 弘行

能登半島の地すべり地の土の工学的性質

「地すべり」Vol. 17，No.2（通巻第62号）1980年（昭和55年）9月

沢崎 雅之, 小川 正二

表層地質における “がけ” 崩壊予知の研究〔第 II 報〕

一伊豆半島, 天城湯ヶ島の持越川支流流域（崩壊模式地）における予知分析一

「地すべり」Vol. 17, No.2（通巻第62号）1980年（昭和55年）9月

井東 澄雄

この報文は “崩壊の予知技術の方法” の理論に基づく分析例としての報告である。

この模式地は，1977年10月から11月までの間に選定した。私はその時から現在までの期間にこの模式地の詳 細な調査を行った。

この分析は，その調查から得たデータにより，前報（I）の理論，とくに図-1，2，3 と数式に従った。この

分析の結果は，表-1〜表-4 に示す。

この結果から, この分析の方法は, 最良の方法という結論になる。 